\title{
Management Practice of Car Production Unit Fire Vocational High School Sumsel in Palembang South Sumatra
}

\author{
Tri Widayatsih ${ }^{1}$, Unifah Rosyidi ${ }^{2}, 3^{\text {rd }}$ Rugaiyah $^{3}$ \\ \{triwidayatsih_mp14s3@mahasiswa.unj.ac.id ${ }^{1}$,Unifahr@unj.ac.id ${ }^{2}$, Rugaiyah@unj.ac.id ${ }^{3}$ \}
}

Universitas Negeri Jakarta, Universitas PGRI Palembang

\begin{abstract}
The purpose of this study is to comprehend how the activities of practical management of production units in Vocational School Sumsel, Palembang, southern Sumatra produce fine products of fire trucks. This research uses qualitative approach with case study method. The focus of it is the practical management in Vocational School Sumsel, sub-focus : practice plan, organization, implementation, and the supervision of the production unit of Vocational School Sumsel. The data collection techniques used are interviews, observations, and documentations. The validity of the data relies on triangulation. Either triangulation of information source, technique, or time. The result of the research planning of production unit has fulfilled the criteria and ran in accordance with the theory of production unit practice planning. The organization of the production unit follows the organizational structure and the detail of management tasks. the implementation of the production unit has opened according to the practice of the education unit by preparing the tools, dividing groups, and assigning tasks and obligation for practice students. The supervision of the production unit of Vocational School Sumsel has been done by sponsors, which is Sumatera high school Diknas, the principal of Vocational School Sumsel, and also teachers and supervisors. There is an order between plan and result of the production unit practice management, but the main and the only one is the production of fire trucks.
\end{abstract}

Keywords: planning, organizing, actuating, controlling, fire truck

\section{Introduction}

Indonesia is a country megadiverse because it has the widest forest and richest biodiversity in the world, Indonesia loses 684,000 ha per year[1] is second only to Brazil. Forest fires in South Sumatra are cases that occur every year, are a local, national, and even international problem. In addition to forest fires, South Sumatra province, especially Palembang, has many densely populated housing. The Disaster Management Center, specifically the Fire Management, currently only has 26 units of fire engines, actually ideally 
it should have 35 fire engines (PK-PB, 2017). The shortage of fire trucks in the city of Palembang, one of which will be answered by the world of education.

The practice of the production unit of the South Sumatra Vocational School, has produced a variety of superior products in 2012-2013, assembling 2 1000L fire jeep fire engines, and 1 fire tanker $3000 \mathrm{~L}$ fire engine, making emergency buildings; prayer place, ablution place, dressing room, bathroom, toilet, ambulance assembly, souvenir; fantasy command sticks, elderly sticks, unique shoe spoons, paddles, sticks, etc. In order to support of the human resource expertise of the South Sumatra Vocational School, both from students, teachers, administrative staff and the management functions of the good South Sumatra Vocational School, all the development and manufacture of superior products have been completed well. Excellent products from various development and manufacturing of superior products in the production units of South Sumatra Vocational School. One of the superior products of fire engines, its existence is needed by the Province of South Sumatra, especially the city of Palembang, in order to provide protection for forests in South Sumatra. In addition it also contributes to extinguishing forest fires which are annual agendas, dense regional fire, or other cases, and even discourse to water plants in Palembang city.

According to the results of the Grand Tour interview with the Head of the Vocational School of Education of South Sumatra Province, of the two hundred and ninety-nine (299) Vocational Schools in South Sumatra only South Sumatra Vocational Schools were able to assemble fire trucks. Its uniqueness is in how the management practices of the production units of the South Sumatra Vocational School can produce superior products, fire engines.

\section{Methodology of Research}

This research was conducted to find out the Practical Management of the Production Unit of the South Sumatra Vocational High School Fire Truck in Palembang City. The study was conducted in South Sumatra Vocational High School, Jalan Jendral Basuki Rahmat no. 2050 Palembang that was conducted for 7 months started from March 2017 to October 2017. Previously, preliminary studies were conducted in order to collect data, namely a preliminary study for proposal writing. This research is a Practical Management Study of the fire extinguisher Production Unit of South Sumatra Vocational High School in Palembang, South Sumatra which was established on July 30, 2010, through Governor Decree Number 529 / KPS / DISDIK / 2010. The development and development of SMKN of South Sumatra is regulated by the Governor of South Sumatra Regulation Number 69 of 2010 dated December 29, 2010. The Provincial Government of South Sumatra wants to make schools that have superior products that can be utilized by the people of South Sumatra Province and realized in the Production Unit Practice Management at South Sumatra Vocational School Palembang, South Sumatra. In 2012-2013, the South Sumatra University through the Production Unit Practice, developed superior products, assembled fire trucks, two (2) pieces of fire jeep, $1000 \mathrm{~L}$ capacity and 1 piece $3000 \mathrm{~L}$. Is the only CBK that produces fire engines in South Sumatra, even in Indonesia, which is badly needed by the Province of South Sumatra, which is prone to forest fires. The flagship product of this fire engine is also a pilot project of the South Sumatra Regional Government, through the Department of Education, with this background a study entitled Management Practices of Mob Production Units. il South Sumatra Civil Service Fire Department in Palembang, South Sumatra. 


\subsection{Research Methods and Procedures}

In this study is qualitative approach that was carried out with the case study method. A qualitative approach is a research procedure that produces descriptive data, speech or writing and behavior that can be observed from people (subjects) themselves or naturalistic approaches in the field of education (Lincoln and Guba, 1985).

\subsection{Data Collection Techniques and Procedures}

Interview, observation and documentation.

\subsection{Analysis of Data Procedure}

Yin divided the three data analysis techniques for case studies, namely (1) match patterning, which is by using the pattern matching logic. Logic like this compares patterns based on empirical data with predicted patterns (or with some alternative predictions). If these two patterns have similarities, the results can strengthen the internal validity of the case studies concerned; (2) explanation making, which aims to analyze case study data by making an explanation of the case in question and (3) time series analysis, which is widely used for case studies that use an experimental approach and quasi-experiment. The procedure of data analysis uses analysis models and qualitative data in accordance with the types of qualitative research methods used by Robert K. Yin Model [3].

\subsection{Validity of Data}

The validity of data is a very important activity in qualitative research that will guarantee the authenticity of findings that will have an impact on solving the problems to be examined. The validity of the data can include: credibility, dependability, transferability, confirmability and triangulation, both triangulation of information sources, technical triangulation, and time triangulation.

\section{The result of the research}

\subsection{Planning}

The practice of the production unit of the South Sumatra Vocational High School, which includes students and teachers involved in the practice and development, preparation of production unit schedules, budgeting and capital preparation, procurement of materials and equipment. Students and teachers involved in the practice of production units, especially the production of fire engines, have met criteria in terms of competence, by means of inventorying competencies, in South Sumatra Vocational School there are four (4) competencies namely Mechatronics Engineering, Light Vehicle Engineering, Electric Power Installation Technique, all competency machining techniques must take part in the Fire Fighting Car Assembly Production Unit practice. Experience of students and teachers, participation in education and training programs. So each competency will be represented by both the students and their teachers. Preparation of the practice schedule for the South Sumatra Vocational School production units starts at 14.30-16.30 for Monday and Wednesday, 14.00-16.30 for Tuesdays and Thursdays, and 14.00-16.30 for Fridays and Saturdays, the schedule hours are adjusted to the hours of compulsory subjects, meaning that the practice schedule of the production units of South Sumatra Vocational School is made 
without disturbing the compulsory education schedule. The schedule starts during the implementation of the production unit's practice unit, until the completion stage, with the expected schedule the production unit practice activities are carried out in accordance with a predetermined time, this is in accordance with Manullang's statement, that in a plan there is an explanation of the start of work and completion of work, both for each and for all work in an activity (Manullang 20). Based on the schedule data, there is one tutor teacher for three (3) or four (4) guiding children (student) practices in the production units of the South Sumatra Vocational School.

To achieve optimal results from a plan, the management practices of the production units of students of South Sumatra Vocational High School have carried out the planning according to its function, where it is said that planning is very important so that the work to be done is more directed, in the management of production units of SMKN South Sumatra planning is the initial part of the implementation, reducing uncertainty, minimizing waste of resources, on the planned planning of what will be achieved (output), who will carry out, how to finance it. Planning for the management practices of the production unit of the fire engine car making of the South Sumatra State Vocational School is the initial part, as stated by W.H. Newman; "Planning is deciding in advance what to be done, that is plan, it is projected a course of action" (Newman William, 2000). That is, planning is the decision of what will be done for the future, namely a plan that is projected in an action. So the management practices of the production unit of students of the South Sumatra Vocational High School are the planning that begins, which is intended to minimize uncertainty, waste of human resources, as stated by Sumardi, that planning has five characteristics, namely, first, planning includes personal and organizational identification; second, planning is closely related to conditions that are relatively definite and uncertain; third, planning is intellectual; fourth, planning regarding future matters; and fifth, planning is pervasive and sustainable.

How are the stages of the work of the Production Unit Practice of the Making of the Fire Truck of the South Sumatra Vocational School, the stages are: Planning, organizing (socialization with students, teachers and employees), implementation, monitoring (evaluation while walking, testing, improvement). Agreement from schools to make fire engine cars by utilizing vocational work practice funds from four (4) Study Programs, namely Electronics Engineering, Automotive Engineering, Electricity Engineering and Mechanical Engineering. So the implementation of all students from the four study programs. Gives various knowledge from various majors.

During the process, not only internal devices play a role but also the external approach, the provincial government of South Sumatra through its Ministry of Education, consultants from the fire department, and the community, the target approach, namely the approach to the output of the fire engine. Furthermore, how are the steps taken in the management of the production unit of students of the South Sumatra Vocational High School, the stages are: Planning, organizing (socialization with students, teachers and employees), implementation, monitoring (evaluation while walking, testing, improvement). Agreement from schools to make fire engine cars by utilizing vocational work practice funds from four (4) Study Programs, namely Electronics Engineering, Automotive Engineering, Electricity Engineering and Mechanical Engineering. So the implementation of all students from the four study programs. Gives various knowledge from various majors.

The idea of the management practice of the production unit of South Sumatra Vocational School students in making fire trucks, was based on: initially the Governor of South Sumatra said that from South Sumatra Vocational High School there must be superior products, then the principal gave one of the superior products, namely fire engines, remembering in 
Palembang natural disasters often occur fires in densely populated settlements, forest fires, and water supply during the dry season. The Governor of South Sumatra Province motivated the Principal of the South Sumatra Vocational School, the principal had welcomed the motivation by making fire trucks, in addition to showing that students of South Sumatra Vocational School were able to produce fire truck products. , and shows students of South Sumatra Vocational High School have very capable expertise. In the matter of determining this fire engine, the headmaster of South Sumatra Vocational School determines the product of fire cars with the reason that it can contribute to the city of Palembang in particular and the province of South Sumatra in general. In this case, the principal has given thoughtful thoughts and choices, which is the creativity of a Principal. In the preparation of the management practices of the South Sumatra production units, the order of preparation of the plan is: Establish / determine the product that will be made, collect relevant data, after determining the fire engine as the product to be made, then the data will be collected, then planning.

\subsection{Organizing}

Judging from the way the organization was carried out in the practice of the production unit of the Vocational High School students of the South Sumatra Vocational High School, with five (5) Ernest Dale's opinions in the Management Book of James A.F. Stoner above, shows the synchronization between what has been carried out in the management practices of the production.

\subsection{Actuating}

This is as stated that, supervision is the measurement and correction of the activities of subordinates to ensure that what is done matches the plan. So supervision measures implementation compared to ideals and plans, shows where there are negative deviations and by mobilizing measures to correct irregularities, helping ensure plans are achieved.

\subsection{Supervision}

The implementation of the fire engine produced by the production unit of Palembang's South Sumatra Vocational School, to be used for the interests of the region / community and show that the South Sumatra Vocational School is able to make it, this implementation is in accordance with the planning. The supervision process is divided into 4 stages, namely: determine the standard or basis for supervision, measuring implementation, compare implementation with standards and find differences if any, deviations by appropriate ways of action.

The basic standard for supervision of the management practices of the production units of students of South Sumatra Vocational School has been determined every three (3) months. When differences are found with the standard, improvements are made according to those specified. The fire engine produced by the management unit of the production unit of the South Sumatra Vocational School is in accordance with what was planned, although there are still some that have not been implemented.

Borrowing procedures through written permission to the South Sumatra Vocational School Principal for things that have been planned, for unplanned fire cases can call directly to the South Sumatra Vocational School and the letter is submitted. But the executor is from the Fire Department, because there is no SOP from the South Sumatra Vocational School. The South Sumatra State Vocational School stated about the results of the fire engine, quite satisfied, but still trying to improve because there are so many shortcomings that still need to be improved, even though the fire engine that has been produced is in accordance with planning. The fire 
engine produced, has gone through a long stage, planning, organizing, moving / implementing, and supervising / evaluating. Supervision is carried out internally ie from within the South Sumatra Vocational High School, the principal as the person in charge, the vice principal as coordinator, productive program teacher, teachers of vocational work practices, and all internal devices. Supervision is also carried out by the Department of Education of South Sumatra Province, especially the Head of the Vocational School. This is as stated, as follows, which says: "In order to achieve the goals of an organization, including the state as an organization of power the biggest should carry out management functions which consist of: planning, organizing, encouraging (actuating), and controlling (controlling). In the practice of the production unit of the manufacture of fire engines of students of South Sumatra State Vocational High School, as follows, every 3 months evaluated, at the testing stage of the fire engine, the evaluation is mainly pipe connections which are carried out by welding. Input: acquisition of materials for the manufacture of fire engines. Process: processing / implementation of input. Output: the result of the processing, which is also commonly called the product, in this case the fire engine.

\section{Conclusion}

The coclusion found in this study are:

4.1 Planning the practice of production units at the South Sumatra Vocational School, in planning the practice of production units, students and teachers involved in the practice of production units, derived from all competencies; Mechatronics Engineering expertise competencies, Light Vehicle Engineering expertise competencies, expertise in Electrical Power Installation Engineering, and Machining Techniques. Preparation of production unit practice schedules, for those serving as production units both teacher and student, gets a schedule after the teaching and learning activities must be completed, namely starting at 2:00 p.m., until 4:30 p.m., for those who are not involved in the execution task, following the schedule of productive course hours. Budget preparation and capital according to the South Sumatra Provincial Budget for the activities of the South Sumatra Vocational School. Procurement of materials and equipment, utilizing the materials and equipment at the Vocational School South Sumatra, and no orders are made, both at home and abroad, depending on the needs and funds available.

4.2 The organization of production unit practices is adjusted to the organizational structure and details of the duties of the board. This includes the division of workload, there is a workload match with the division of labor, difficulties in completing workloads. and dare to take the risk.

4.3 The practice of the production unit of the South Sumatra Vocational School, begins with the implementation activities, namely the preparation of the production unit practices, by preparing equipment, dividing groups of students who practice, and assigning the duties and obligations of students who are practicing..

4.4 Supervision of production units in South Sumatra Vocational School, monitoring of production unit practices has been carried out, by various parties, Head of Education Department of South Sumatra Province, Principal, productive subject teacher / supervisor, there is a match between the plan and the results, there is suitability students, and monitor financial statements. Evaluation of production unit practices, carried out on products produced 
in this case fire trucks. Can provide feedback and can take advantage of evaluation results for the development of production units.

\section{References}

[1] Harold Koontz dan cyril o'Donnel, Principle of Management an Analysis of Managerial Function. Tokyo: Mc Graw Hill Kogakusha (1972).

[2] Hendra Cipta, Setiap Tahun Hutan Indonesia Kehilangan 684.000 ha , Jakarta: Kompas.com, (2016).

[3] Ibnu Syamsi, Pokok-pokokOrganisasi dan Manajemen(Jakarta: PT. Remaja Rosda karya, (1994).

[4] Irham Fahmi. Manajemen: Teori, Kasus, dan Solusi.(Bandung: Alfabeta, 2012).

[5] Maman Ukas, Manajemen Konsep, Prinsip dan Aplikasi. Bandung: Ossa Promo (1999).

[6] Newman, William, H. The Process of Management :Concrpt, Behavior and Practice.( New Delhi:Prentice Hall of India Pvt, Ltd. 2000).

[7] Popi Tuhulele, Kebakaran Hutan di Indonesia dan Proses Penegakan Hukumnya Sebagai Komitmen dalam Mengatasi Dampak Perubahan Iklim,Jurnal Supremasi hukum, vol.3 No.2, Desember (2014).

[8] Robert K. Yin. Case Study Design and Methodes. Washington: Cosmos Corporation. (1989.)

[9] Yayat Sudaryat, StrategiPengembanganManajemen Unit Produksi Sebagai Penujang Pelaksanaan Pendidikan Sistem Ganda di SMKTI N6 dan BLPT Bandung, UPI Bandung,( 2013). 